\title{
Innovation and modernization of the Russian energy sector
}

\author{
Wadim Strielkowski ${ }^{1,2,}{ }^{*}$, Gordon Rausser, ${ }^{1}$ and Oksana Takhumova ${ }^{3}$ \\ ${ }^{1}$ Department of Agricultural and Resource Economics, University of California, Berkeley, Giannini \\ Hall, CA 94720 Berkeley, United States \\ ${ }^{2}$ Centre for Energy Studies, Prague Business School, Werichova str. 1145/29, 15200 Prague, Czech \\ Republic \\ ${ }^{3}$ Federal State Budgetary Educational Institution of Higher Education "Kuban State Agrarian \\ University named after I. T. Trubilin”, Kalinina str. 13, 350044 Krasnodar, Russian Federation
}

\begin{abstract}
Russian energy sector is suffering from the economic, financial, and political sanctions imposed by the United States and the European Union. These sanctions have prevented Russia from accessing oil and gas resources and from exporting natural gas. Low oil prices, combined with sanctions against Russia, can be blamed as a possible cause of Russia's collapse as an energy producer and consumer. However, the country is struggling to modernize its energy balance. Specifically, Russia's major modernisation efforts have focused on the energy sector and related industries and services. In support of economic growth and social development, the 2003 Energy Strategy made substantial investments in energy infrastructure, such as the construction of new power stations, transmission lines and power plants. This paper focuses on the recent innovation and modernization trends of the Russian energy sector. It discusses the history and the developments in this sector up to this day, provides some insights into modernization efforts of the sector and describes the perspectives for the deployment of the renewable energy sources.
\end{abstract}

\section{Introduction}

In some cases, renewable energy is needed and governments encourage people to invest in it and use it. There are a number of programmes to qualify projects and equipment for the renewable energy sources. These include a variety of projects, such as solar, wind, geothermal, biomass, hydropower, biofuel, solar and wind energy [1]. These grant and loan programs can be awarded by several government agencies. According Krupa and Harvey, there is an average of $\$ 1.5$ billion in funding available for the renewable energy grant programs each year. In addition, there is research and development support for renewable energy technologies such as wind turbines [2]. These funds can help support the development of domestically produced wind turbine components used in the United States. The Recovery Act increases the ability of the U.S. Department of Energy to manufacture the nation's most advanced wind and solar power plants domestically. The Business Council for Sustainable

\footnotetext{
* Corresponding author: strielkowski@berkeley.edu
} 
Energy focused on the economic growth through sustainable energy development. Energy policy decisions are based not on the opinions of an individual or group of people, but on a national consensus. These partnerships work closely with state, local and federal authorities, as well as private sector partners, to facilitate the development of new projects and promote their environmental and economic benefits [3].

In the United Kingdom, renewables accounted for more than half of installed capacity the country's electricity sector. Since 2008, solar power generation has tripled and wind power has tripled. Funding for the Recovery Act has helped to develop new technologies such as wind and solar, and has cut costs to make the UK energy sector more competitive in the global renewable energy market [4,5]. A number of reforms are underway to create a more competitive electricity market that favours renewable energy. Under the new rules for the renewable energy market, auctions for renewable energy will take place and an opt-out clause allowing energy suppliers to restrict coal-fired generation will level the playing field at national level. Stakeholders aim to introduce inflexible nuclear power into the electricity grid, but does not include a ban on the construction of new nuclear power plants or the closure of all coal-fired power stations.

The Biden administration underscored its commitment to reducing greenhouse gas emissions when it announced the United States' commitment to formally join the Paris Agreement in February 2021. This development came as no surprise due to the intention to accelerate the development of renewable energy sources and reduce the country's dependence on fossil fuels such as coal, oil, and gas. In the United States, decarbonization is accelerating and being driven by market forces. The world's largest coal-fired power plants in China produce more than 1,000 megawatts (MW) of electricity in 2015, with renewables replacing nearly half of the country's fossil-fuel generation capacity [6]. In the United States, California is currently promoting energy efficiency measures, including cogeneration, to reduce energy demand and move away from fossil fuels. This includes updating the Energy Efficiency and Resource Standards (EERS) to require energy suppliers to save a certain percentage of electricity and natural gas in order to support their more aggressive targets [7]. Ohio provided an example of this when it passed HB 6, which expanded support for Ohio's nuclear power plants by reducing the state's RPS and eliminating its EERS over the next seven years. New Mexico and Washington, both recently adopted CES targets, have adopted complementary policies, with New Mexico requiring a 50\% reduction in electricity and natural gas consumption by 2030, while Washington has expanded its EERS to natural gas for the first time. By introducing a new 100\% EER and establishing a more aggressive $50 \%$ EPS, Nevada eliminates efficiency measures from the program, while preserving the ability to give utilities flexibility to achieve short-term goals [8].

In the Russian Federation, the situation is quite different. Russian energy sector is obsolete and robust with lots of grim heritage from the Soviet past and its megalomanic energy projects. Currently, there is a pressing need to modernize Russian energy industry and steer it towards the path of renewable energy sources and green technologies [9, 10]. This paper draws from the experience of the Western countries and discusses the lessons and implications for the Russian energy sector.

\section{Dependence of Russian economy of fossil fuels}

One of the most important steps to reduce Russia's risk of oil shocks is economic diversification. This is made more difficult by the fact that the non-oil sector accounts for less than $1 \%$ of total gross domestic product (GDP). Moreover, Russia is the world's secondlargest exporter of oil and gas after the United States. Russia's main oil and gas fields are depleted, but Russia continues to expand its oil and gas production and receives government 
revenues in the short term [11]. Figure 1 that follows reports Russian total energy supply for the past 18 years divided by source.

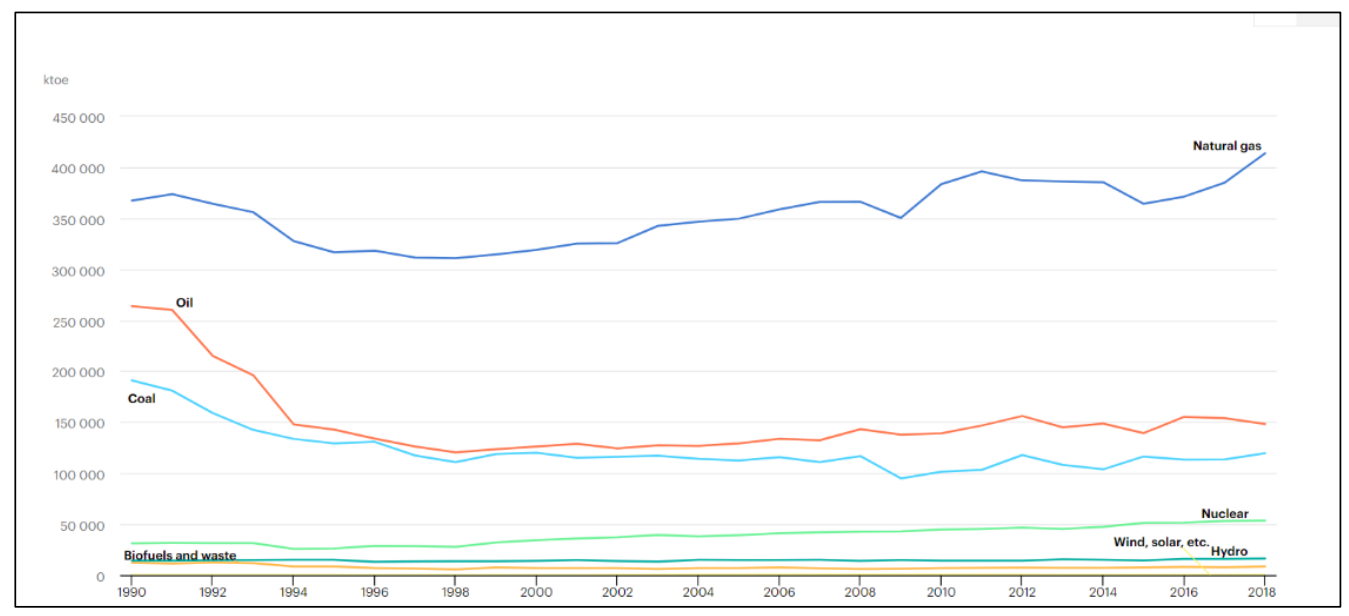

Fig. 1. Russian total energy supply by source (1990-2018) [12].

In the recent years, Russia's three largest oil and gas producing regions have experienced a $10 \%$ decline in output over the past decade. The central importance of hydrocarbons to the Russian economy is not a new issue, but it is worth rethinking it today. New technologies are making natural resources cheaper and more plentiful, threatening billions in government revenues [13]. To maintain, let alone increase, current production levels, Russia must make concerted efforts to explore and recover oil and gas resources in the Middle East, North Africa, and South America. Over the years, oil and gas revenues have remained the main source of income for the Russian economy and the main driver of its economic growth. Since the 2000s, several government initiatives have sought to promote the oil and gas industry, including the Ministry of Natural Resources and Energy, which is at the centre of Russia's economic growth and development, especially in the energy sector. But, despite the strong relationship between oil prices and the economy, Russian policymakers have failed to create new economic capacity from the oil and gas sector [14]. Despite the positive relationship with oil price shocks, Russian economic growth has had a negative relationship with the price of oil in recent years. Just to remind that in the neoclassical school of economics, oil is believed to be the primary source of economic growth for oil-exporting countries such as the United States and Russia. As a result, the economic growth of oil-exporting countries seems to have various effects on their development. It therefore seems that the oil and gas revenues of the United States and Russia, as well as of other oil exporters, have had different effects on these countries' economic development [15].

The current research attempts to paint a more detailed picture of the impact of oil and gas revenues on Russia's economic development by taking into account the impact of oil - the economic growth of exporting countries on their inflation. Russia's economic growth has been positive for the past three years, with average annual inflation of $2.5 \%$. Moreover, data from the United States, Russia, and other oil-exporting countries suggest that these countries have experienced significant changes in their "inflation" over the past two years. As a result, rising oil and gas revenues tend to be accompanied by improvements in the federal government's budget balance. The fluctuations in the value of oil and gas exports affect economic activity in Russia in two ways. First, they provide the bulk of their income to the Russian state, and second, the state finances its budget in part by selling state assets. In 2015, tax revenues were decimated by an economy that had slipped into recession and in 2015-16 
by the collapse of the oil and gas industry. As the growth rate of Russia's oil, gas, and mining industries slowed, policymakers adopted fiscal rules to ensure that revenues from the sale of state assets, such as natural gas and oilfields, were not available for household spending.

\section{Innovation activities in Russian energy sector}

These innovations are expected to ensure the country's energy security and reduce its dependence on Western technology and equipment. Major Russian fuel and energy companies are gradually adopting digital and smart technologies, including "Made in Russia," that reflect advanced global trends [16]. In the oil and gas sector, some of the most promising areas of innovative development, beyond increasing oil production, are the development of hard-to-access oil reserves, including shelf zones, and the production of liquefied natural gas (LNG) and its by-products. The section entitled "Oil industry development programmes" contains a series of objectives aimed at creating conditions under which the oil industry can function and achieve good financial and economic indicators. The adoption of this program demonstrates the state's interest in the FEC's technological modernization. It should also be noted that the Government of the Russian Federation has approved the development of new technologies for the production of liquefied natural gas (LNG) and its by-products. The introduction of a new gas storage facility in Russia and the expansion of existing underground storage facilities demonstrate the need for a more efficient and cost-effective method of storing and transporting liquefied natural gas. Innovation in the Russian energy sector and the development of new technologies for the production of liquefied natural gas and by-products. The mineral resources sector remains one of the most important sectors of the Russian economy and contributes a large part of the tax revenue to the budget. Oil and gas revenues still account for more than $42 \%$ of the total, but the share from other sectors such as mining, mining and mining services is lower at less than $20 \%$ [17]. The new company's work will be geared towards financing new technologies, i.e. acting as functional cross-cutting technologies and facilitating digitisation in this crucial sector. This will ensure that the funds have a positive impact on the development of the energy sector and the economy as a whole. The funds will also help reduce dependence on imported technologies and promote the export of "Russian solutions," as this is a global industry. Innovation is one of the most important practical tools to ensure the development of the Russian energy sector and other external and internal challenges that Russia has faced in recent years. By implementing the innovation and development strategy adopted by the Government of the Russian Federation in 2011, the region has created core elements of an innovative ecosystem. Regional innovation clusters have been established and institutions supporting innovation development have started their activities. According to the annual list of innovation developments in each region prepared by the Association of Innovative Regions of Russia, it corresponds to the level of innovators in the media sector. The Stavropol region has consolidated its position in key rankings that assess the level of innovation development.

The developments in the gas industry up to 2020 are linked to the construction of the Power Siberia 2 gas pipeline, which is intended to secure Russian gas supplies to China [18]. The strategy envisages the development of new technologies to overcome existing problems in the Russian energy sector, such as the use of natural gas as an energy source and the production of renewable energy. The Russian government and the Russian Oil and Gas Association (ROGA) have signed the world's first long-term investment agreement for the development of energy technologies. The government's fiscal measures, primarily related to the increase in the Federal Economic Fund (FEC) and the reduction in tax rates, will increase investment in the industry, boost production and increase budget revenues. The Russian FEC will ensure that it is responsible for the development of new energy technologies and the 
production of natural gas and renewable energy. In addition, the government has obtained approval for an extreme measure to increase export duties on petroleum products, which will allow to regulate supply to domestic markets and thus prevent a sharp increase in retail fuel prices.

\section{Renewable energy projects in Russia}

Currently, there opens a new era of renewable energy development in Russia and as an important step in the development of the country's energy sector even though it is associated with numerous risks [19]. At the moment, very few of the Russia's electricity is generated from renewable sources. RusHydro's hydroelectric power plants were built and commissioned by the Russian Ministry of Natural Resources and Energy, the Federal Service for the Development of Renewable Energies and the State Duma. By 2024, solar and wind power generation in Russia is expected to reach $1 \%$. Gazprom, the oil and gas company that supplies more than $80 \%$ of Russia's total electricity generation capacity, is of course going vegan in the foreseeable future and is ready to wear sandals. But at least this latest move has put some green leaves on the plate, not the green- leaves - of the fig variety. According to Gazprom, RusHydro's hydropower production will be built and put into operation with an output of 1,000 megawatts (MW) per year. The move is seen as a harbinger of a shift away from fossil fuels to renewable energy sources such as wind and solar [20].

Unlike nuclear power plants, solar panels and solar systems are not able to provide constant, stable and new electricity generation around the clock. The distribution of this additional income to the population will have significant social consequences. The Kalmykia solar power plant will be built in conjunction with the construction of a new nuclear power plant, which is scheduled to take place in 2018-2019. In addition to the investment decisions already taken, Fortum and its joint venture will also honour their commitment to meet the needs of Russian consumers facing increasing pressures to manage their greenhouse gas emissions and climate change. The agreement signed by Fortum, AB InBev and Unilever for 2018-2019 is the first practical step to meet the demand for renewable energy in Russia's energy-intensive economy. Under the agreement, Fortum will supply the electricity generated by its wind and solar farms to all of its production facilities throughout Russia [21]. The availability of oil, gas and coal has stifled the development of clean energy. The problem is that the current funding mechanism expires in 2024, Russia's unambitious renewable-energy targets are met almost on time through ambitious localization, and the influx of foreign renewable-energy developers will stop in the near future, creating new incentives for renewable energy.

While Russia is the fourth largest producer of electricity in the world, it is ranked $109^{\text {th }}$ in renewable energy production. Russia theoretically has the potential to increase its share of renewable energy to $4.9 \%$ by 2025 , up from $3.5 \%$ in 2014 [22]. But analysts and industry officials say the situation in Russia is unlikely to change much until the coming coronavirus pandemic, even if the world's largest economy provides significant additional funds to fight climate change and accelerate decarbonization. Therefore, we do not see the Russian economy restarting the trend of using zero-carbon technologies and investing in zero-carbon projects [23-25].

\section{Conclusions}

All in all, modernization of the vast Russian energy system includes increased gasification in all Russian regions, the development of energy infrastructure in Eastern Siberia and the Far East, as well as full integration into the Russian energy infrastructure system and, in 
particular, the commercial development of the Arctic and North Sea routes. In addition, ES2035 stipulates that Russia will expand its production of hydrogen and helium in the country to become one of the world's leading suppliers of hydrogen. Under this objective, two LNG clusters on the Yamal and Gyda peninsula will be completed. This is achieved through the use of domestically produced technologies, which fell short of the import and substitution strategy that Russia introduced in 2014. The 2003 Energy Strategy was aimed at creating an innovative and efficient energy sector, and there were efforts to increase the oil refinery, improve the quality of oil products and develop the oil-related chemical industry and the construction of new energy infrastructure. In the current draft energy strategy for 2035, the overarching objective will be the qualitative renewal and modernisation of the energy sectors. The main task of the country's leadership is to maintain the lowest possible energy tariffs for as long as possible, including reducing the technological security of energy infrastructure by developing effective systems that encourage modernisation through the introduction of energy-saving technologies. As for renewables, by incentivizing them the Russian government can determine its energy balance, which is quite difficult without a decarbonization agenda. Russia sees real value in renewable energy sources such as wind, solar, geothermal, and hydropower. This will reduce energy costs, help solve environmental problems and improve the efficiency of the wider energy infrastructure, including the transmission and distribution system and the energy storage and transmission system. The Far East economy is heavily energy-oriented, and the coal extracted in the Far East is largely exported and consumed by the people of the region. Eastern energy policy in Russia is crucial as part of regional economic policy to solve the problems of energy security, environmental protection and economic development. The united energy system of Russia is bound by a decree of the Government of the Russian Federation from the end of the Second World War and the beginning of the Soviet Union. From 2019, a unified electricity system will be connected with the construction of a new nuclear power plant in Krasnoyarsk, Russia's second largest city. The connection will be limited in some parts of the country, which must be excluded in order to reduce the possibility for new companies to enter the energy supply market by importing energy from neighbouring energy systems. These companies own the power stations in Russia's Far East and supply more than $90 \%$ of the electricity to the Far East. The companies also ensure the transport of electricity and at the same time manage the distribution of energy to end users and the supply of gas and electricity to power plants. Russian gross electricity production in 2008 amounted to $1,038 \mathrm{TWh}$, placing it in the 4th place among global producers. Vestas Manufacturing Rus has located wind turbines in the Far East, while Siemens, Gamesa Lagerwey and other wind power companies have also entered the Russian market. Until 2008, the Russian Federation was the second largest producer of wind energy in Europe after Germany and China and the third largest in AsiaPacific.

The availability of oil, gas and coal has stifled the development of clean energy. In theory, Russia has the potential to increase its share of renewable energy to $4.9 \%$, but the problem is that the current funding mechanism will expire in 2024, and Russia's unambitious renewable-energy targets (ambitious localization is almost always met) and inflows of foreign renewable-energy developers will end, creating new incentives for renewable energy.

\section{References}

1. M. Simionescu, W. Strielkowski, M. Tvaronavičienè, Energies, 13 (9), 2280 (2020)

2. J. Krupa, L. Harvey, Energy, 135, 913-929 (2017)

3. J. Nahm, Business and Politics, 19 (1), 68-106 (2017) 
4. W. Strielkowski, E. Volkova, L. Pushkareva, D. Streimikiene, Energies, 12 (7), 1392 (2019)

5. F. Li, E. Trutnevyte, Applied Energy, 189, 89-109 (2017)

6. G. Wang, J. Deng, Y. Zhang, Q. Zhang, L. Duan, J. Hao, J. Jiang, Science of The Total Environment, 741, 140326 (2020)

7. H. Cho, A. Freyre, M. Bürer, M. Patel, Energy Policy, 135, 111010 (2019)

8. L.C. Stokes, Interest groups and the battle over clean energy and climate policy in the American States (Oxford University Press, Oxford, 2020)

9. E. Lisin, W. Strielkowski, Transformations in Business \& Economics, 13 (2B), 566-580 (2014)

10. N. Kapustin, D. Grushevenko, Energy Policy, 117, 198-207 (2018)

11. O. Kirichenko, A. Komzolov, Y. Nazarova, N. Shcherbakova, T. Kirichenko, International Journal of Energy Economics and Policy, 10 (3), 112-118 (2020)

12. IEA, https://www.iea.org/countries/Russia (2021)

13. R. Connolly, P. Hanson, M. Bradshaw, Eurasian Geography and Economics, 61 (4-5), 511-531 (2020)

14. W. Strielkowski, A. Sherstobitova, P. Rovny, T. Evteeva, Energies, 14 (11), 3164 (2021)

15. L. Popova, F. Jabalameli, E. Rasoulinezhad, World Sociopolitical Studies, 1 (1), 1-31 (2017)

16. L. Kapranova, O. Ermolovskaya, E. Tyutyukina, L. Chernikova, Revista Espacios, 40 (30), 1-15 (2019)

17. M. Bradshaw, T. Van de Graaf, R. Connolly, Energy Strategy Reviews, 26, 100374 (2019)

18. V. Kutcherov, M. Morgunova, V. Bessel, A. Lopatin, Energy Strategy Reviews, 30, $100511(2020)$

19. G. Chebotareva, W. Strielkowski, D. Streimikiene, Journal of Cleaner Production, 269, $122110(2020)$

20. E. Gavrikova, Y. Burda, V. Gavrikov, R. Sharafutdinov, I. Volkova, M. Rubleva, D. Polosukhina, Resources, 8 (2), 84 (2019)

21. D. Borovikov, Fortum catches the wind in Russia (2019). Access mode: https://www.fortum.com/about-us/blog-podcast/forthedoers-blog/fortum-catches-windrussia

22. P. Rutland, New Political Economy, 13 (2), 203-210 (2019)

23. E. Lisin, Y. Marishkina, W. Strielkowski, D. Streimikiene, Economic researchEkonomska istraživanja, 30 (1), 1820-1828 (2017)

24. E. Lisin, D. Shuvalova, I. Volkova, W. Strielkowski, Sustainability, 10 (4), 1111 (2018)

25. K. Lee, C. Fyson, C. Schleussner, Environmental Research Letters, 16 (9), 094001 (2021) 